\title{
Seasonal variation in the photo-physiology of homogeneous and heterogeneous Symbiodinium consortia in two scleractinian corals
}

\author{
K. E. Ulstrup ${ }^{1,2,4, *}$, R. Hill' ${ }^{1}$, M. J. H. van Oppen ${ }^{2}$, A. W. D. Larkum ${ }^{3}$, P. J. Ralph ${ }^{1}$ \\ ${ }^{1}$ Institute for Water \& Environmental Resource Management, Department of Environmental Science, \\ University of Technology, Sydney, PO Box 123, Broadway, New South Wales 2007, Australia \\ ${ }^{2}$ Australian Institute of Marine Science, PMB No. 3, Townsville MC, Queensland 4810, Australia \\ ${ }^{3}$ School of Biological Sciences (A08), University of Sydney, New South Wales 2006, Australia
}

${ }^{4}$ Present address: Marine Biological Laboratory, Department of Biology, University of Copenhagen, Strandpromenaden 5, 3000 Helsingør, Denmark

\begin{abstract}
Seasonal variation in the composition of the algal endosymbiont community and photophysiology was determined in the corals Pocillopora damicornis, which show high local fidelity to one symbiont type (Symbiodinium C1), and Acropora valida, with a mixed Symbiodinium symbiont community, comprising members of both clades A and C. The relative abundances of Symbiodinium types varied over time. A significant decline in symbiont densities in both coral species during the summer of 2005 coincided with a NOAA 'hotspot' warning for Heron Island. This also coincided with a relative increase in the presence and dominance of clade A in A. valida, particularly in sun-adapted surfaces. The effective quantum yield of Photosystem II ( $\left.\Phi_{\mathrm{PSII}}\right)$ suggested that sun-adapted surfaces of $P$. damicornis are more sensitive than shade-adapted surfaces to combined effects of higher temperature and irradiance in summer. Xanthophyll cycling was greater in P. damicornis than A. valida, irrespective of branch position and sampling time; this may be a mechanism by which $P$. damicornis compensates for its fidelity to Symbiodinium C1. Furthermore, xanthophyll de-epoxidation in P. damicornis symbionts was greater in sun-adapted than shade-adapted surfaces, correlating with non-photochemical quenching $\left(\mathrm{NPQ}_{\mathrm{RLC}}\right)$. No variation was found in A. valida, indicating that resident symbiont communities may not have been physiologically compromised, perhaps as a result of changes in the composition of the Symbiodinium community consortia.
\end{abstract}

KEY WORDS: Fast fluorescence kinetics $\cdot$ ITS1 rDNA $\cdot$ LSU rDNA $\cdot$ Symbiodinium $\cdot$ Symbiont density

\section{INTRODUCTION}

Symbiotic algae of the genus Symbiodinium (zooxanthellae) are genetically diverse and are thought to play an important role in the acclimatisation and/or adaptation of corals to changes in the environment (Baker 2003). The relative abundances of genetically different Symbiodinium types forming heterogeneous symbiont consortia in corals may change over time scales of months, seasons and years (e.g. Toller et al.
2001, Little et al. 2004, Berkelmans \& van Oppen 2006, Thornhill et al. 2006) in response to changes or disturbances in the environment (Toller et al. 2001, Berkelmans \& van Oppen 2006). Genetically different types of Symbiodinium also exhibit distinct physiologies, some of which may mitigate the effects of coral bleaching conditions (Rowan 2004).

Evidence of different physiologies was initially sought among Symbiodinium ex symbio (Chang et al. 1983, Iglesias-Prieto \& Trench 1994). However, incon- 
sistencies between phylogenetic and physiological attributes (Savage et al. 2002b, Tchernov et al. 2004, Robison \& Warner 2006), and between physiological responses of isolated versus in hospite Symbiodinium (Bhagooli \& Hidaka 2003, Goulet et al. 2005) suggest that the coral host, at least in part, determines the fitness of the holobiont. The photo-physiological response of Symbiodinium is influenced by photoprotective agents such as antioxidant enzymes (e.g. Lesser \& Shick 1989) and heat-dissipating pigments (Ambarsari et al. 1997) as well as host-associated fluorescent pigments that scatter and fluoresce light (Salih et al. 2000). Photosynthetic processes of Symbiodinium are also influenced by their local irradiance regime, which is controlled by water depth and light scattering properties of coral tissues (Enríquez et al. 2005). Thus, photo-physiological differences have been documented between sun- and shade-adapted colonies (Falkowski \& Dubinsky 1981, Porter et al. 1984, Gorbunov et al. 2001), between sun- and shade-adapted surfaces of individual colonies (Jones et al. 1998, Ralph et al. 2005), and between polyp and coenosarc tissues (Kühl et al. 1995, Ralph et al. 2002, 2005, Hill et al. 2004b, Ulstrup et al. 2006b).

The photo-protective process of excess excitation energy dissipation away from the photosynthetic apparatus (non-photochemical quenching, NPQ) is usually enhanced by high irradiance exposure (Warner et al. 1996, Gorbunov et al. 2001, Warner \& Berry-Lowe 2006). The formation of diatoxanthin (Dt) by deepoxidation of diadinoxanthin (Dn) is one of the dissipation pathways that is also thought to be important for the scavenging of reactive oxygen species (Ambarsari et al. 1997, Lesser et al. 2000, Brown et al. 2002, Venn et al. 2006, Warner \& Berry-Lowe 2006). We studied the effect of seasonal acclimatisation on the proportion of xanthophyll cycling (Dt/(Dn + Dt)) in coral symbionts at low irradiances as a proxy for dissipation capacity.

Photo-acclimatisation of Symbiodinium operates on a variety of time scales and by different mechanisms. At high irradiances, coral polyps use behavioural mechanisms such as tissue retraction for shade (Brown et al. 2002), or tissue expansion to increase the surface area for solute exchange, which may alleviate potential carbon limitation and excess oxygen levels in the tissue (Levy et al. 2006). Diurnal (Brown et al. 1999a, Jones \& Hoegh-Guldberg 2001, Levy et al. 2004, Hill \& Ralph 2005) and seasonal changes in irradiance (Brown et al. 1999b, Fitt et al. 2000, Warner et al. 2002) as well as temperature cause modulation of symbiont photosynthesis that affects photochemical efficiency. Also, Symbiodinium cell density is inversely correlated to seasonal increases in light and temperature (Fagoonee et al. 1999, Fitt et al. 2000). Finally, tempo- ral patterns of symbiont population density, pigment content and photochemical efficiency related to seasonal changes in environmental conditions may also be partially due to changes in the phylogenetic composition of symbiotic communities associated with corals (Fitt et al. 2000, Warner et al. 2002, Baker 2003).

There have been few long-term studies of genetic flexibility (Goulet \& Coffroth 2003, Thornhill et al. 2006) and photo-physiological variation (Brown et al. 1999b, Fitt et al. 2000, Warner et al. 2002) of symbiont communities in hospite, and to our knowledge, never in combination. We report the intra-colony variability of physiological responses and Symbiodinium composition in Pocillopora damicornis and Acropora valida monitored twice yearly for $3 \mathrm{yr}$ at Heron Island in the southern section of the Great Barrier Reef, Australia.

\section{MATERIALS AND METHODS}

Pocillopora damicornis (Linnaeus) and Acropora valida (Dana) colonies were collected twice yearly over a $1 \mathrm{wk}$ period in the austral summer (January) and winter (July) of 3 consecutive years (2004-2006) in the Heron Island lagoon $\left(23^{\circ} 26.6^{\prime} \mathrm{S}, 151^{\circ} 54.7^{\prime} \mathrm{E}\right)$. Sea surface $(1$ to $3 \mathrm{~m})$ temperature at Heron Island was obtained from the daily monitoring program at Heron Island Research Station between January 2004 and August 2006. A spirit thermometer was used to record the minimum and maximum daily temperature over the previous $24 \mathrm{~h}$. The maximum temperature observed each day was used to map the thermal variation for the duration of this study (see Fig. 1).

Corals were collected haphazardly at $<3 \mathrm{~m}$ depth in the afternoon in each season in a localised area of $\sim 0.5$ ha adjacent to Heron Island Research Station. Pocillopora damicornis is very abundant in the lagoon area in front of the station; Acropora valida is less abundant. Collections of $A$. valida were therefore limited to a small number of colonies $(<15)$, most of which would have been re-sampled between years. An upward-facing branch (sun-adapted) and a basal (shade-adapted) branch of individual fragments of each of 10 colonies were sub-sampled for each of the following analyses: rapid light curve (RLC), fast induction curve (FIC), symbiont density, xanthophyll pigmentation and genetic identification of symbiont communities. All measurements were examined after dusk on the day of collection following a minimum of 1 to $2 \mathrm{~h}$ of acclimation to irradiances between 25 and $35 \mu \mathrm{mol}$ photons $\mathrm{m}^{-2} \mathrm{~s}^{-1}$ provided by a flood light calibrated to a quantum irradiance meter (LI-190 cosine corrected, Li-Cor). This low illumination was intended to keep the photosynthetic apparatus active and prevent any dark-induced reduction of the electron trans- 
port chain via chlororespiration (Garab et al. 1989, Peltier \& Cournac 2002, Beardall \& Quigg 2003), which has been shown to be active in corals (Jones \& HoeghGuldberg 2001, Ulstrup et al. 2005).

PAM fluorescence measurements of Photosystem II. An RLC with $10 \mathrm{~s}$ intervals between 9 irradiance steps was performed by placing a $6 \mathrm{~mm}$ fibre-optic cable fitted to a Diving-PAM (Pulse-Amplitude-Modulation) (Walz; settings for the PAM: Gain $=2$, Damping $=2$ ) adjacent to the coral, approximately $3 \mathrm{~cm}$ from the tip of a branch. The Diving-PAM employs $3 \mu$ s pulses from a red light-emitting diode (LED) with a peak emission at $650 \mathrm{~nm}$ as the measuring light $(0.15 \mu \mathrm{mol}$ photons $\mathrm{m}^{-2} \mathrm{~s}^{-1}$ ). Saturation pulses were of $>4500 \mu \mathrm{mol}$ photons $\mathrm{m}^{-2} \mathrm{~s}^{-1}$ for $0.8 \mathrm{~s}$. Chl a fluorescence was detected at wavelengths $>710 \mathrm{~nm}$. The basic parameters measured were $F_{t}$ (the fluorescence yield in the light at time $t$ ) and $F_{\mathrm{m}}$ ' (the maximum fluorescence yield in the light induced by a saturating flash of light). From these parameters, the effective quantum yield of Photosystem II $\left(\Phi_{\mathrm{PSII}}=\left[F_{\mathrm{m}}{ }^{\prime}-F_{\mathrm{t}}\right] / F_{\mathrm{m}}{ }^{\prime}\right)$ and relative electron transport rate $\left(\mathrm{rETR}=\left[F_{\mathrm{m}}{ }^{\prime}-F_{t}\right] / F_{\mathrm{m}}{ }^{\prime} \times \mathrm{PAR}\right)$ were derived, where PAR is the photosynthetically active radiation in $\mu$ mol photons $\mathrm{m}^{-2} \mathrm{~s}^{-1}$. RLCs (rETR measured over a range of irradiances between 0 and $1800 \mu \mathrm{mol} \mathrm{m}^{-2} \mathrm{~s}^{-1}$ ) were subsequently fitted to the formula of Platt et al. (1980), whereby quantitative parameters of maximum relative electron transport rate $\left(\mathrm{rETR}_{\max }\right), \alpha$ (light utilisation coefficient) and $E_{k}$ (minimum saturating irradiance) were calculated. The highest $\Phi_{\mathrm{PSII}}\left(\left[F_{\mathrm{m}}{ }^{\prime}-F_{t}\right] / F_{\mathrm{m}}{ }^{\prime}\right)$ was derived from the first measure of the RLCs in light ( 25 to $35 \mu \mathrm{mol}$ photons $\mathrm{m}^{-2} \mathrm{~s}^{-1}$ ). Finally, nonphotochemical quenching $\left(\mathrm{NPQ}=\left[F_{\mathrm{m}}-F_{\mathrm{m}}{ }^{\prime}\right] / F_{\mathrm{m}}{ }^{\prime}\right)$ was calculated for irradiances between 800 and $1000 \mu \mathrm{mol}$ photons $\mathrm{m}^{-2} \mathrm{~s}^{-1}$ for each RLC (NPQ $\mathrm{RLC}$ ), depending on sampling season. The actinic light intensities of the Diving-PAM were calibrated before each sampling period. The irradiance settings for each season were chosen to approximate each other. The individual irradiance steps, however, could not be replicated between seasons due to possible decay of the battery, probe and LEDs of the Diving-PAM.

Fast induction kinetics of Photosystem II. Upon completion of an RLC, a FIC was measured using the Plant Efficiency Analyser (PEA) (Hansatech, Instruments) after 5 min of dark-acclimation in a purposebuilt chamber (Hill et al. 2004b). Fast induction kinetics provide detailed information on the photochemical state of PSII, as well as the plastoquinone (PQ) pool (Govindjee 1995, Hill et al. 2004a). The array of 6 red LEDs (peak wavelength $650 \mathrm{~nm}$ ) produced the saturating irradiance (3200 $\mu \mathrm{mol}$ photons $\mathrm{m}^{-2} \mathrm{~s}^{-1}$ ) focusing on an area $4 \mathrm{~mm}$ in diameter approximately $3 \mathrm{~cm}$ from the tip of the branch. A PIN-photodiode (shielded by a long-pass filter $>720 \mathrm{~nm}$ ) detected the fluorescence signal from the in hospite symbionts. The fluorescence signal was obtained over $2 \mathrm{~s}$ and recorded every $10 \mu \mathrm{s}$ for the first $2 \mathrm{~ms}$, every $1 \mathrm{~ms}$ for the first $1 \mathrm{~s}$ of sampling, and every $100 \mathrm{~ms}$ thereafter. The base fluorescence $\left(F_{0}\right)$ was measured at $0.05 \mathrm{~ms}(\mathrm{O}$ step), the $\mathrm{J}$ step at $1.5 \mathrm{~ms}$, the I step at $50 \mathrm{~ms}$ and the P step $\left(F_{\mathrm{m}}\right)$ was recorded as the maximum fluorescence was reached at the end of the $2000 \mathrm{~ms}$ sampling period. The amplitude of each step along the FICs was plotted for the 2 coral species for sun- and shade-adapted coral surfaces (see Fig. 5). Maximum quantum yield $\left(F_{\mathrm{v}} / F_{\mathrm{m}}=\left[F_{\mathrm{m}}-F_{0}\right] / F_{\mathrm{m}}\right)$ was calculated from the $\mathrm{O}$ step (at $50 \mu \mathrm{s}$ ) and $\mathrm{P}$ step (maximum fluorescence), which are equivalent to $F_{0}$ and $F_{\mathrm{m}}$, respectively (see Fig. 4 ). $F_{\mathrm{v}} / F_{\mathrm{m}}$ was also determined the following morning prior to sunrise.

The OJIP transient (nomenclature of Strasser et al. 1995) can be divided into 2 phases, the fast rise from the minimum fluorescence $(\mathrm{O})$ to $\mathrm{J}$ and onwards to the intermediate I step, and a slower rise to the P step (Hill et al. 2004a). The rise in fluorescence from O to J corresponds to the reduction of the PSII primary electron acceptor $\mathrm{Q}_{\mathrm{A}}$ to $\mathrm{Q}_{\mathrm{A}}{ }^{-}$(Strasser et al. 1995, Ulstrup et al. 2005). Following the $J$ step, further reduction of $Q_{A}$ and, subsequently, $Q_{B}$ (secondary electron acceptor of PSII) occurs up until the I step (Strasser et al. 1995, Srivastava et al. 1997). The final component of the fluorescence rise to the $\mathrm{P}$ step is ascribed to the filling of the PQ pool (Lavorel \& Etienne 1977, Lazar 2006), which takes approximately $2 \mathrm{~s}$ in corals (Hill \& Ralph 2005, Ulstrup et al. 2005).

Molecular methods. A $\sim 30 \mathrm{~mm}$ length coral piece was fixed in $95 \%$ ethanol for later sample processing to genetically identify the resident symbiont community. The DNA of preserved coral samples $(\mathrm{N}=240)$ was extracted using the DNeasy ${ }^{\mathrm{TM}}$ Tissue Kit (Qiagen). Single-stranded conformation polymorphism (SSCP) and sequence analysis of the rDNA ITS1 region were used as markers for identification (van Oppen et al. 2001); PCR and gel conditions are described in Ulstrup \& van Oppen (2003). Where the ITS1 PCR protocol failed to amplify ( $10 \%$ of samples), LSU (large subunit) was amplified using the protocol specified in van Oppen et al. (2001) with the assumption that the 2 primers have equal affinities for the different Symbiodinium types amplified. LSU resolves Symbiodinium types to sub-clade levels C1 and C2 (sensu van Oppen et al. 2001). Ten $\mu$ l of PCR product were combined with $10 \mu \mathrm{l}$ of RFLP mix $\left(0.3 \mu \mathrm{l}\right.$ TaqI $\left(10\right.$ units $\left._{\mu \mathrm{l}^{-1}}\right), 2 \mu \mathrm{l} 10 \times$

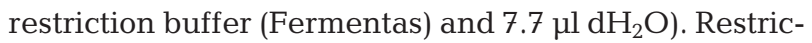
tion digests were analysed by running an aliquot $(5 \mu \mathrm{l})$ on a $2 \%$ TAE-agarose gel $(1 \mathrm{~h}, 80 \mathrm{~V})$ stained with ethidium bromide, and representatives of disparate profiles were sequenced (Macrogen). Finally, sequences were compared to those stored in GenBank (available at: www.ncbi.nlm.nih.gov). 
Symbiont cell determination. The densities of symbionts were determined as number of cells $\mathrm{cm}^{-2}$. Coral tissue was stripped from an approximately $3 \mathrm{~cm}$ long branch using an air-gun and submerged in $1 \mu \mathrm{m}$ filtered seawater. Symbiont cell densities in $10 \mathrm{ml}$ aliquots were determined from the average of 8 replicate haemocytometer counts, standardised to the liquid volume in which they were extracted and related to the coral surface area using the wax weight method (Stimson \& Kinzie 1991) for triplicate samples. The regression relationship was determined empirically using acrylic cylinders with a range of known surface areas $\left(\mathrm{r}^{2}=0.998\right)$.

Symbiont xanthophyll determination. The relative proportions of Dt to the total xanthophyll pool (Dt + Dn) were determined using reverse-phase high performance liquid chromatography (HPLC). Upon completion of chl a fluorescence measurements of PSII, approximately $3 \mathrm{~cm}$ long sun- and shade-adapted branches from each colony collected were snap frozen in liquid nitrogen and placed in a freezer at $-80^{\circ} \mathrm{C}$ until further analysis. Coral tissue (including symbionts) was removed from each branch using sonication and subsequently spun at $5000 \times g$ for $10 \mathrm{~min}$. Resulting pellets were extracted in $2 \mathrm{ml}$ acetone and vortexed for $30 \mathrm{~s}$. The extract was spun using high-speed centrifugation $(10000 \times g)$ for $5 \mathrm{~min}$, and the clarified supernatant extract $(150 \mu \mathrm{l})$ was loaded into the autosampler for immediate injection onto a Phenomenex C18 column (5 $\mu \mathrm{m}$ particle size, $250 \times 4.6 \mathrm{~mm})$ at room temperature $\left(21^{\circ} \mathrm{C}\right)$. All samples were prepared under low light.

Analyses were performed on a PC-interfaced HPLC system (Shimadzu). System control, data collection and integration were performed using Class-VP v. 6 Shimadzu 2002 software. Pigments were separated using a binary mobile phase system $(60 / 40[\mathrm{w} / \mathrm{v}]$ methanol/ $1.0 \mathrm{M}$ ammonium acetate: $95 \%$ methanol) over $10 \mathrm{~min}$ followed by an isocratic hold at $95 \%$ methanol for

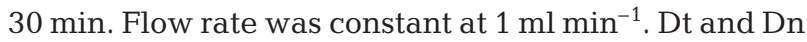
were detected using a photodiode array (PDA) detector and pigments were identified by spectral recognition (Jeffrey et al. 1997). Absorbance chromatograms were extracted at $440 \mathrm{~nm}$. The xanthophyll ratio was calculated as the ratio of area of the peak corresponding to Dt to the peak area of Dt + Dn.

Statistical analyses. Coral specimens $(n=10)$ of Pocillopora damicornis and Acropora valida were collected in the summer and winter of 2004, 2005 and 2006. Changes in photo-physiological parameters and symbiont cell densities among sampling times (seasons, years) and positions (sun- and shade-adapted surfaces) were assessed by repeated measures ANOVAs. Each species was analysed separately, year was treated as a within-subject factor, and season and position as between-subject factors. Where ANOVA determined a significant difference, Box's test of equality of covariance matrices was used to test the homogeneity of variances across groups. Where the assumption of homogeneity was violated, the data were $\log _{10}$-transformed. When this transformation failed to produce homoscedasticity, significant differences indicated by the test were accepted if $p<0.01$. The assumption of sphericity was tested and, if violated, the Greenhouse-Geisser adjustment was performed (Quinn \& Keough 2002). Post-hoc comparisons of means for significant factors and interactions were carried out using Tukey's HSD tests. Parameters analysed were $F_{\mathrm{v}} / F_{\mathrm{m}}, \Phi_{\mathrm{PSII}}$, descriptive parameters of fitted RLC curves $\left(\mathrm{rETR}_{\max }, \alpha\right.$ and $\left.E_{\mathrm{k}}\right)$, descriptive parameters of FICs $\left(\mathrm{O}, \mathrm{J}, \mathrm{I}\right.$, and P), NPQ $\mathrm{RLC}_{\mathrm{RL}}$, symbiont cell density and $\mathrm{Dt} /(\mathrm{Dn}+\mathrm{Dt})$. In the case of $F_{\mathrm{v}} / F_{\mathrm{m}}$ derived from FICs, each sun- and shade-adapted surface of each species was also analysed separately, year was treated as within-subject factor, and season and time (dusk and dawn) as between subject factors. Statistical significance of the ANOVAs was accepted at $p<0.05$. All analyses were performed with STATISTICA v. 7.1 software (SysSoft).

\section{RESULTS}

\section{Measurements of temperature}

Fig. 1 shows the maximum temperature regime observed in the Heron Island lagoon where corals were collected between January 2004 and July 2006. Although coral paling was observed during the summer in all years of this study, Heron Island was considered a coral bleaching 'hotspot' (Goreau \& Hayes 1994) only in the summer of 2005. In the lagoon, bleaching was manifested as greater-than-normal paling of branching corals, but no mortality was observed at the time of collection.

\section{Quantum yields}

The $\Phi_{\text {PSII }}$ (derived from the first measure of the RLCs in light at 25 to $35 \mu \mathrm{mol}$ photons $\mathrm{m}^{-2} \mathrm{~s}^{-1}$ ) and the $F_{\mathrm{v}} / F_{\mathrm{m}}$ (measured with the PEA) were greater on shadeadapted surfaces than in sun-adapted surfaces of Pocillopora damicornis ( $\Phi_{\mathrm{PSII}}: F_{1,36}=65.91, \mathrm{p}<0.001$; $F_{\mathrm{v}} / F_{\mathrm{m}}: F_{1,36}=88.10, \mathrm{p}<0.001$; Figs. 2a \& 3a). Significant interactions were observed between effects of season and position on $\Phi_{\text {PSII }}\left(F_{1,36}=20.97, \mathrm{p}<0.001\right)$ for $P$. damicornis, suggesting that the branch orientation influenced the variation between seasons.

Sun-adapted surfaces of Acropora valida had lower $F_{\mathrm{v}} / F_{\mathrm{m}}$ than shade-adapted surfaces $\left(F_{1,36}=17.81, \mathrm{p}<\right.$ 


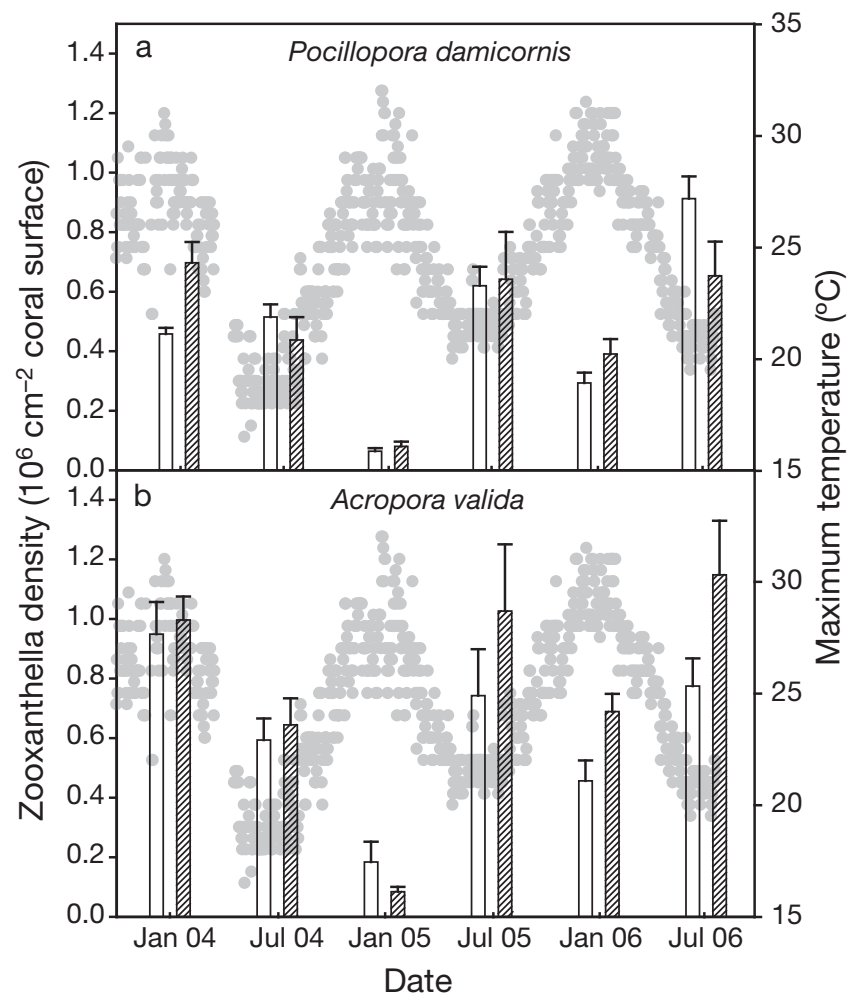

Fig. 1. (a) Pocillopora damicornis and (b) Acropora valida. Maximum daily seawater temperatures (๑) at Heron Island and symbiont cell densities of corals in sun- (white bars) and shade-adapted surfaces (hatched bars) of colonies. Means + $\mathrm{SE}, \mathrm{n}=10$

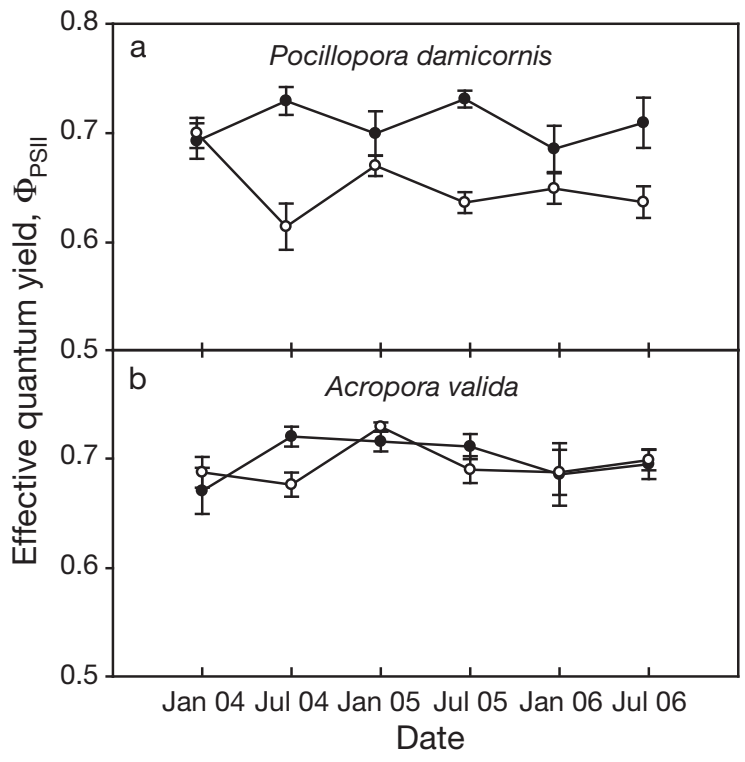

Fig. 2. (a) Pocillopora damicornis and (b) Acropora valida. Effective quantum yield $\left(\Phi_{\mathrm{PSI}}\right)$ measured for corals under quasi-darkness conditions in sun- (O) and shade-adapted $(\bullet)$ surfaces at dusk. Means $\pm \mathrm{SE}, \mathrm{n}=10$

0.001, Fig. 3b), whereas there was no intra-colony differentiation in $\Phi_{\text {PSII }}$ (Fig. 2b). $F_{\mathrm{v}} / F_{\mathrm{m}}$ in summer fluctuated between years, with lower values in 2004 and 2006 than in $2005\left(F_{2,72}=10.19, \mathrm{p}<0.001\right.$, Fig. 3c).

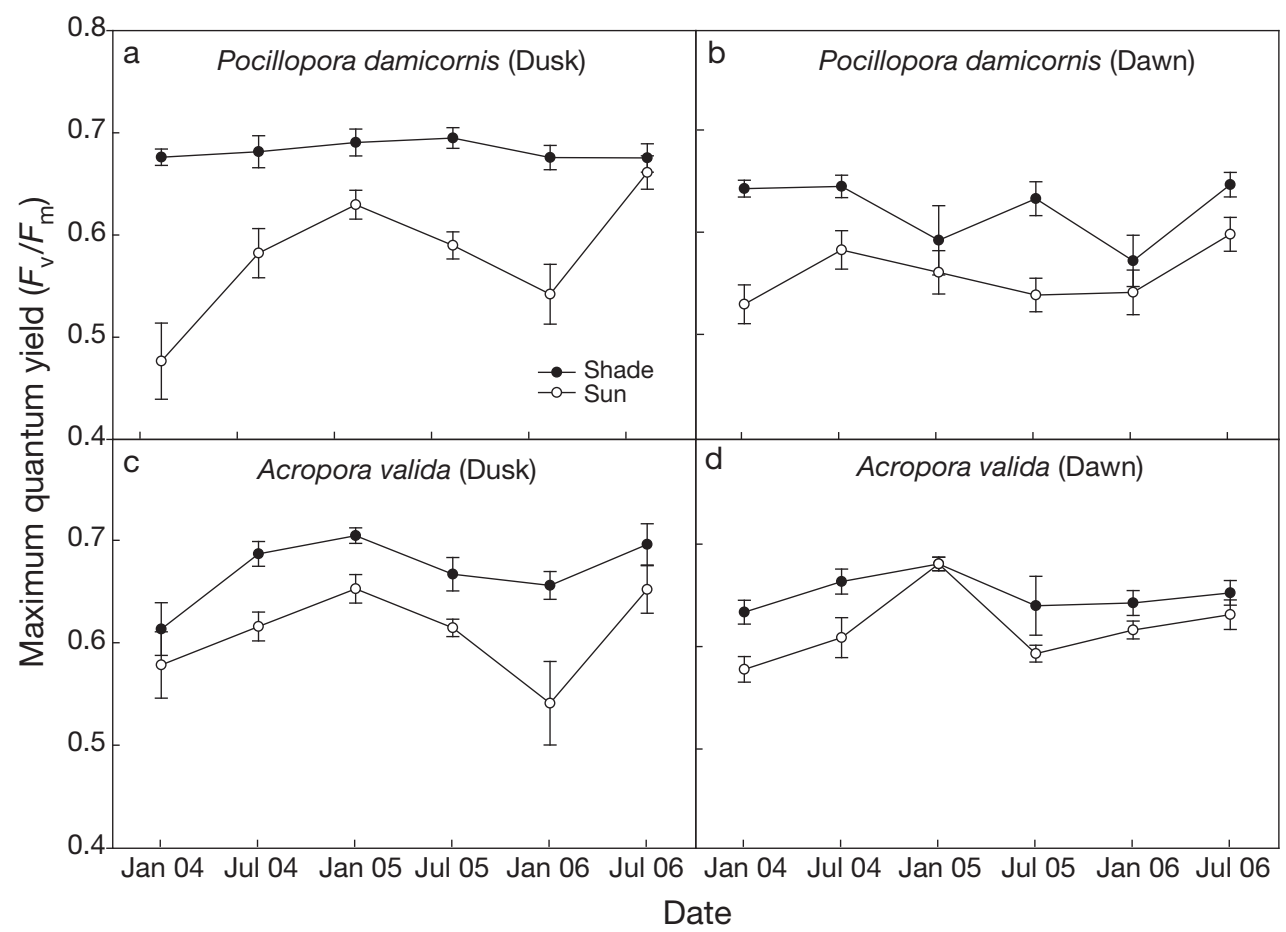

Fig. 3. (a,b) Pocillopora damicornis and $(\mathrm{c}, \mathrm{d})$ Acropora valida. Maximum quantum yield $\left(F_{\mathrm{v}} / F_{\mathrm{m}}\right)$ of zooxanthellae in sun- $(\mathrm{O})$ and shade-adapted $(\bullet)$ surfaces of corals at $(\mathrm{a}, \mathrm{c})$ dusk and $(\mathrm{b}, \mathrm{d})$ dawn. Means $\pm \mathrm{SE}, \mathrm{n}=10$ 
The differences between dusk and dawn measurements of $F_{\mathrm{v}} / F_{\mathrm{m}}$ for sun- and shade-adapted surfaces, respectively, were also tested. Shade-adapted surfaces of Pocillopora damicornis yielded higher $F_{\mathrm{v}} / F_{\mathrm{m}}$ values at dusk than at dawn $\left(F_{1,36}=26.92, \mathrm{p}<0.001\right.$, Fig. 3).

\section{Descriptive parameters of fitted rapid light curves}

The descriptive parameters of fitted RLCs revealed lower rETR $_{\max }$ in shade-adapted than in sun-adapted surfaces of Pocillopora damicornis $\left(F_{1,36}=14.30, \mathrm{p}<\right.$ $0.001)$ and Acropora valida $\left(F_{1,36}=25.14, \mathrm{p}<0.001\right)$

Table 1. Pocillopora damicornis and Acropora valida. Quantitative parameters derived from fitted rapid light curves as a function of PAR. Variable chl a fluorescence: $\mathrm{rETR}_{\max }$ (maximum relative electron transport rate, a.u. [arbitrary units]), $\alpha$ (light utilisation coefficient), $E_{k}$ (minimum saturating irradiance, $\mu$ mol photons $\mathrm{m}^{-2} \mathrm{~s}^{-1}$ ); values are for sun- (Sun) and shade-adapted (Shade) corals in summer and winter over 3 consecutive years. Means $\pm \mathrm{SE}, \mathrm{n}=10$

\begin{tabular}{|c|c|c|c|c|}
\hline & & $\mathrm{rETR}_{\max }$ & $\alpha$ & $E_{k}$ \\
\hline \multicolumn{5}{|c|}{ P. damicornis } \\
\hline \multicolumn{5}{|c|}{2004} \\
\hline \multirow[t]{2}{*}{ Summer } & Sun & $114 \pm 6$ & $0.75 \pm 0.03$ & $155 \pm 12$ \\
\hline & Shade & $87 \pm 5$ & $0.66 \pm 0.03$ & $134 \pm 9$ \\
\hline \multirow[t]{2}{*}{ Winter } & Sun & $108 \pm 7$ & $0.62 \pm 0.03$ & $178 \pm 14$ \\
\hline & Shade & $102 \pm 7$ & $0.75 \pm 0.03$ & $138 \pm 13$ \\
\hline \multicolumn{5}{|l|}{2005} \\
\hline \multirow[t]{2}{*}{ Summer } & Sun & $168 \pm 22$ & $0.71 \pm 0.02$ & $243 \pm 38$ \\
\hline & Shade & $152 \pm 19$ & $0.72 \pm 0.01$ & $208 \pm 25$ \\
\hline \multirow[t]{2}{*}{ Winter } & Sun & $80 \pm 4$ & $0.56 \pm 0.04$ & $147 \pm 10$ \\
\hline & Shade & $65 \pm 4$ & $0.66 \pm 0.03$ & $100 \pm 7$ \\
\hline \multicolumn{5}{|l|}{2006} \\
\hline \multirow[t]{2}{*}{ Summer } & Sun & $145 \pm 17$ & $0.50 \pm 0.03$ & $291 \pm 36$ \\
\hline & Shade & $121 \pm 9$ & $0.49 \pm 0.03$ & $252 \pm 22$ \\
\hline \multirow[t]{2}{*}{ Winter } & Sun & $171 \pm 5$ & $0.61 \pm 0.04$ & $292 \pm 24$ \\
\hline & Shade & $151 \pm 13$ & $0.64 \pm 0.04$ & $242 \pm 26$ \\
\hline \multicolumn{5}{|l|}{ A. valida } \\
\hline \multicolumn{5}{|l|}{2004} \\
\hline \multirow[t]{2}{*}{ Summer } & Sun & $79 \pm 8$ & $0.46 \pm 0.04$ & $172 \pm 13$ \\
\hline & Shade & $56 \pm 10$ & $0.42 \pm 0.06$ & $132 \pm 18$ \\
\hline \multirow[t]{2}{*}{ Winter } & Sun & $93 \pm 8$ & $0.55 \pm 0.04$ & $176 \pm 16$ \\
\hline & Shade & $59 \pm 4$ & $0.73 \pm 0.02$ & $82 \pm 6$ \\
\hline \multicolumn{5}{|l|}{2005} \\
\hline \multirow[t]{2}{*}{ Summer } & Sun & $138 \pm 13$ & $0.75 \pm 0.03$ & $187 \pm 18$ \\
\hline & Shade & $133 \pm 12$ & $0.73 \pm 0.02$ & $186 \pm 20$ \\
\hline \multirow[t]{2}{*}{ Winter } & Sun & $87 \pm 5$ & $0.56 \pm 0.03$ & $162 \pm 14$ \\
\hline & Shade & $44 \pm 4$ & $0.67 \pm 0.03$ & $68 \pm 7$ \\
\hline \multicolumn{5}{|l|}{2006} \\
\hline \multirow[t]{2}{*}{ Summer } & Sun & $142 \pm 17$ & $0.47 \pm 0.03$ & $297 \pm 21$ \\
\hline & Shade & $92 \pm 10$ & $0.48 \pm 0.05$ & $199 \pm 17$ \\
\hline \multirow[t]{2}{*}{ Winter } & Sun & $158 \pm 10$ & $0.63 \pm 0.02$ & $252 \pm 14$ \\
\hline & Shade & $103 \pm 10$ & $0.58 \pm 0.04$ & $184 \pm 17$ \\
\hline
\end{tabular}

(Table 1). $E_{k}$ was also lower in shade-adapted than in sun-adapted surfaces of $P$. damicornis $\left(F_{1,36}=15.38\right.$, $\mathrm{p}<0.001)$ and $A$. valida $\left(F_{1,36}=35.23, \mathrm{p}<0.001\right)$. For both species, $E_{k}$ was lower in winter than in summer (P. damicornis: $F_{1,36}=8.21, \mathrm{p}=0.007 ; A$. valida: $F_{1,36}=$ $13.93, \mathrm{p}=0.001)$. A significant interaction $\left(F_{1,36}=10.33\right.$, $\mathrm{p}=0.003$ ) was observed for $\alpha$ between season and position for $P$. damicornis, suggesting that branch orientation influenced the light utilisation efficiency between seasons.

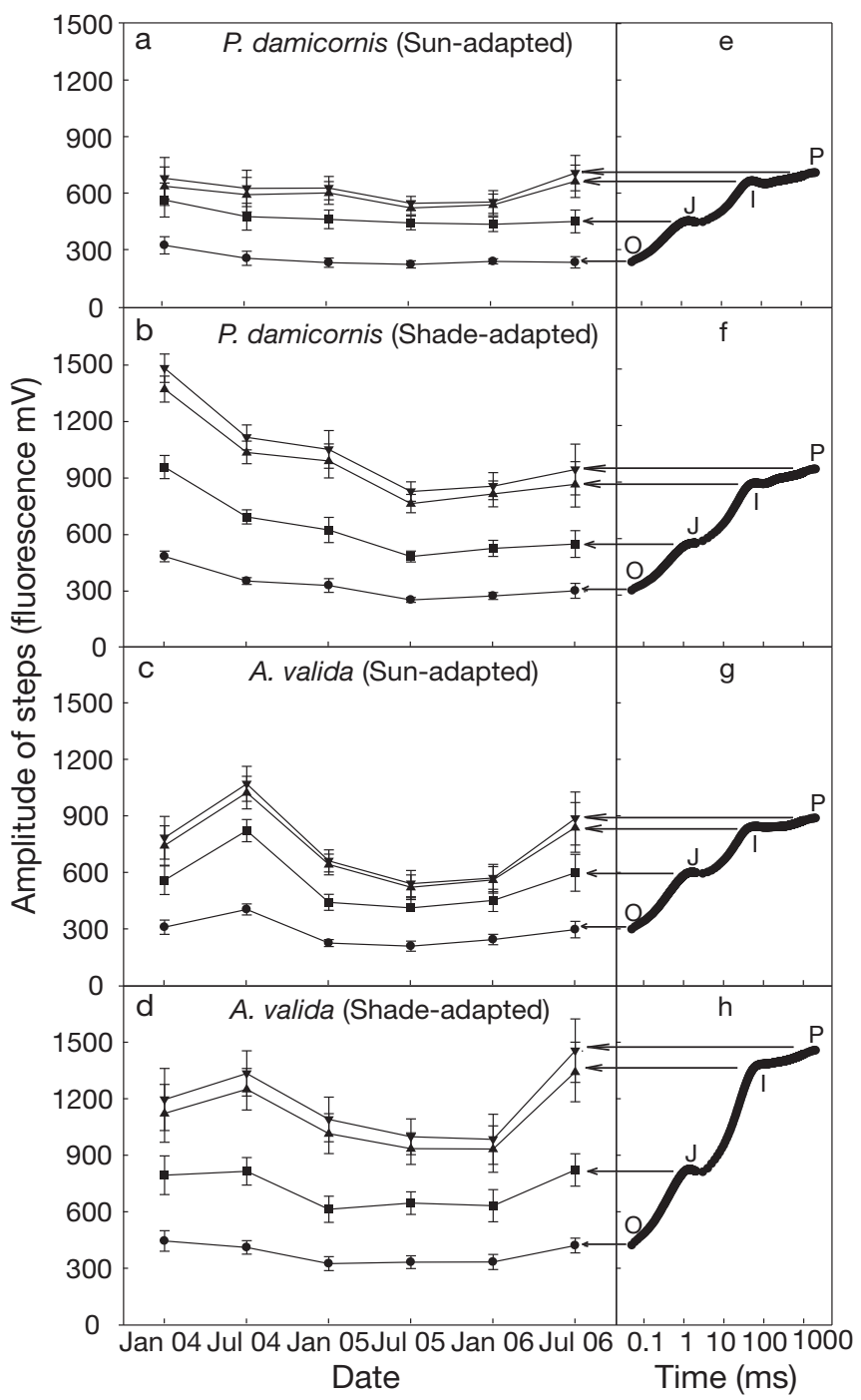

Fig. 4. Pocillopora damicornis and Acropora valida. Amplitude of the $\mathrm{O}, \mathrm{J}, \mathrm{I}$ and $\mathrm{P}$ steps $(\boldsymbol{\bullet}, \mathbf{\square}, \boldsymbol{\Delta}$ and $\boldsymbol{\nabla}$, respectively) along fast induction curves (FICs) in P. damicornis: (a) sunand (b) shade-adapted surfaces, and in A. valida: (c) sun- and (d) shade-adapted surfaces between January 2004 and July $2006(\mathrm{n}=10$, mean $\pm \mathrm{SE})$. Average FICs $(\mathrm{n}=10)$ from P. damicornis on (e) sun- and (f) shade-adapted surfaces, and from A. valida on (g) sun- and (h) shade-adapted surfaces indicating how $\mathrm{O}, \mathrm{J}$, I and P step amplitudes were obtained. Arrows correlate to the amplitude of each of the steps for these particular FICs 


\section{Fast induction kinetics}

The mean amplitudes of the O, J, I and P steps along the FICs measured on sun- and shade-adapted surfaces of Pocillopora damicornis and Acropora valida from January 2004 to July 2006 are shown in Fig. 4a-d. Fig. 4e,f display the average FICs of sun- and shadeadapted surfaces of $P$. damicornis in July 2006; Fig. 4g, h display equivalent data for $A$. valida. These provide an example of how the O, J, I and P step amplitudes were derived for Fig. $4 \mathrm{a}-\mathrm{d}$. In all cases, the O, J, I and P step amplitudes of the shade-adapted surfaces were higher than those of the sun-exposed surfaces (Fig. 4). The differences in the P step for both $P$. damicornis and $A$. valida indicate a reduction in $F_{\mathrm{m}}$ and are also reflected in the lower $F_{\mathrm{v}} / F_{\mathrm{m}}$ values for $P$. damicornis of sun-adapted surfaces compared to shadeadapted surfaces (Fig. 3a,b).

In Pocillopora damicornis, all steps declined in the years following 2004 (O: $F_{2,72}=12.84, p<0.001$; J: $F_{2,72}=12.05, \mathrm{p}<0.001 ; \mathrm{I}: F_{2,72}=7.74, \mathrm{p}<0.001 ; \mathrm{P}:$ $F_{2,72}=8.40, \mathrm{p}<0.001$; Fig. $\left.4 \mathrm{a}, \mathrm{b}\right)$ and for the $\mathrm{O}$ and $\mathrm{I}$ steps alone in winter $\left(\mathrm{O}: F_{1,36}=9.10, \mathrm{p}<0.005\right.$; I: $\left.F_{1,36}=4.39, \mathrm{p}=0.043\right)$. A significant interaction was observed between season and position for the $\mathrm{J}$ step $\left(F_{1,36}=4.40, \mathrm{p}=0.043\right)$, suggesting that the seasonal variation in amplitude of this parameter depended on branch orientation (Fig. 4a,b).

In Acropora valida, the $\mathrm{O}$ step declined in the years following $2004\left(F_{2,72}=11.47, \mathrm{p}<0.001\right)$, while the J, I and $\mathrm{P}$ steps were lower only in $2005\left(\mathrm{~J}: F_{2,72}=9.18\right.$, p < $\left.0.001 ; \mathrm{I}: F_{2,72}=5.47, \mathrm{p}=0.006 ; \mathrm{P}: F_{2,72}=5.24, \mathrm{p}=0.008\right)$ (Fig. $4 \mathrm{c}, \mathrm{d}$ ). For J, I and $\mathrm{P}$, there were also rises in winter $\left(\mathrm{O}: F_{1,36}=5.44, \mathrm{p}=0.025 ; \mathrm{J}: F_{1,36}=5.88, \mathrm{p}=0.021\right.$; $\left.\mathrm{P}: F_{1,36}=6.55, \mathrm{p}=0.015\right)$. For the I and $\mathrm{P}$ steps, there was a significant interaction between year and season (I: $F_{2,72}=4.27, \mathrm{p}=0.018 ; \mathrm{P}: F_{2,72}=4.46, \mathrm{p}=0.015$ ) showing that the winter of 2005 was lower than in 2004 and 2006 (Fig. 4c,d).

\section{Variability in Symbiodinium types harboured}

Over the course of $3 \mathrm{yr}$, the population of Pocillopora damicornis experienced no variation in symbiont type (C1 sensu van Oppen et al. 2001, GenBank Accession \# AY457958). Acropora valida colonies hosted a variety of clade $\mathrm{C}$ types, including $\mathrm{C} 1$ and $\mathrm{C} 2$ (sensu van Oppen et al. 2001, GenBank Accession \# AY758477.1) as well as a member of clade A (GenBank Accession \# AF380513) (Table 2). The strain belonging to clade A occurred simultaneously with Symbiodinium C2 and sometimes also with Symbiodinium C1. In the samples where LSU was used, clade A could not be resolved simultaneously to $\mathrm{C} 1$ as the restriction profile of clade
A overlaps that of $\mathrm{C} 1$. This may therefore have led to a slight underestimation of the presence of clade A in $\sim 10 \%$ of samples.

Symbiodinium C2 was the dominant symbiont type in Acropora valida across sampling times and appeared in all specimens except for one sun-adapted surface sample in the summer of 2006. Symbiodinium C1 appeared in $\sim 54 \%$ of all samples but was never dominant. In the summer of 2004 and winter of 2005, C1 was absent from all samples. Clade A was detected mostly in sun-adapted surfaces of corals and was particularly prevalent in the summer and winter of 2005 and in the winter of 2006 (Table 2).

Table 2. Pocillopora damicornis and Acropora valida. Frequencies of Symbiodinium type(s) within sun- and shadeadapted surfaces (Sun, Shade) and among colonies from Heron Island. $\mathrm{n}$ : sample number; $f$ : observed SSCP (singlestranded conformation polymorphism) genotype frequencies (for clades $\left.\mathrm{A}, \mathrm{C}[\mathrm{C} 1, \mathrm{C} 2], \mathrm{D}: f_{\mathrm{A}}, f_{\mathrm{C} 1}, f_{\mathrm{C} 2}, f_{\mathrm{D}}\right) ; \%$ : proportions of clades. Where $>1$ Symbiodinium type was present, the dominant frequency is in bold; -: no data

\begin{tabular}{|c|c|c|c|c|c|c|c|c|}
\hline & & $\mathrm{n}$ & $f_{\mathrm{A}}$ & $\%$ & $f_{\mathrm{C} 1}$ & $\%$ & $f_{\mathrm{C} 2}$ & $\%$ \\
\hline \multicolumn{9}{|c|}{ P. damicornis } \\
\hline \multicolumn{9}{|c|}{2004} \\
\hline \multirow[t]{2}{*}{ Summer } & Sun & 8 & - & - & 8 & 100 & - & - \\
\hline & Shade & 3 & - & - & 3 & 100 & - & - \\
\hline \multirow{2}{*}{ Winter } & Sun & 10 & - & - & 10 & 100 & - & - \\
\hline & Shade & 9 & - & - & 9 & 100 & - & - \\
\hline \multicolumn{9}{|l|}{2005} \\
\hline \multirow[t]{2}{*}{ Summer } & Sun & 9 & - & - & 9 & 100 & - & - \\
\hline & Shade & 8 & - & - & 8 & 100 & - & - \\
\hline \multirow[t]{2}{*}{ Winter } & Sun & 10 & - & - & 10 & 100 & - & - \\
\hline & Shade & 9 & - & - & 9 & 100 & - & - \\
\hline \multicolumn{9}{|l|}{2006} \\
\hline \multirow[t]{2}{*}{ Summer } & Sun & 7 & - & - & 7 & 100 & - & - \\
\hline & Shade & 10 & - & - & 10 & 100 & - & - \\
\hline \multirow[t]{2}{*}{ Winter } & Sun & 2 & - & - & 2 & 100 & - & - \\
\hline & Shade & 3 & - & - & 3 & 100 & - & - \\
\hline \multicolumn{9}{|l|}{ A. valida } \\
\hline \multicolumn{9}{|l|}{2004} \\
\hline \multirow[t]{2}{*}{ Summer } & Sun & 10 & $1(\mathbf{1})$ & 10 & - & - & $10(\mathbf{9})$ & 100 \\
\hline & Shade & 8 & - & - & - & - & 8 & 100 \\
\hline \multirow[t]{2}{*}{ Winter } & Sun & 9 & $3(\mathbf{1})$ & 33 & 4 & 44 & $9(5)$ & 100 \\
\hline & Shade & 8 & 1 & 13 & 2 & 25 & $8(7)$ & 100 \\
\hline \multicolumn{9}{|l|}{2005} \\
\hline \multirow[t]{2}{*}{ Summer } & Sun & 9 & $6(3)$ & 67 & 7 & 78 & $9(5)$ & 100 \\
\hline & Shade & 9 & 1 & 11 & 7 & 78 & $9(8)$ & 100 \\
\hline \multirow[t]{2}{*}{ Winter } & Sun & 7 & $5(2)$ & 71 & - & - & $7(5)$ & 100 \\
\hline & Shade & 8 & 8 & 100 & - & - & $8(8)$ & 100 \\
\hline \multicolumn{9}{|l|}{2006} \\
\hline \multirow[t]{2}{*}{ Summer } & Sun & 10 & $3(2)$ & 30 & 1 & 10 & $9(2)$ & 90 \\
\hline & Shade & 10 & - & - & - & - & 10 & 100 \\
\hline \multirow[t]{2}{*}{ Winter } & Sun & 9 & $4(4)$ & 44 & 7 & 78 & $9(6)$ & 100 \\
\hline & Shade & 7 & $2(1)$ & 29 & 5 & 71 & $7(7)$ & 100 \\
\hline
\end{tabular}




\section{Symbiont density}

No evidence of intra-colony differentiation in symbiont cell density was detected in Pocillopora damicornis or Acropora valida. Seasonal changes in the density of symbionts were observed in both coral species with summer density being lower than winter density $(P$. damicornis: $F_{1,36}=132.8, \mathrm{p}<0.001 ;$ A. valida: $F_{1,36}=$ 49.39, $\mathrm{p}<0.001$ ). In both species, there was a significant decline in symbiont density in summer 2005 (P. damicornis: $F_{2,72}=18.72, \mathrm{p}<0.001 ; A$. valida: $F_{2,72}=$ $57.45, \mathrm{p}<0.001$, Fig. 1). This correlated with the bleaching conditions in that year, resulting in a pronounced paling of corals in the lagoon.

\section{Xanthophyll cycling and $\mathbf{N P Q}_{\mathrm{RLC}}$}

Pocillopora damicornis showed a greater proportion of Dt to the total pool of Dn + Dt than Acropora valida irrespective of orientation of the coral surface (Fig. 5). Sun-adapted surfaces of $P$. damicornis colonies had a greater proportion of $\mathrm{Dt}$ to the total pool of $\mathrm{Dn}+\mathrm{Dt}$

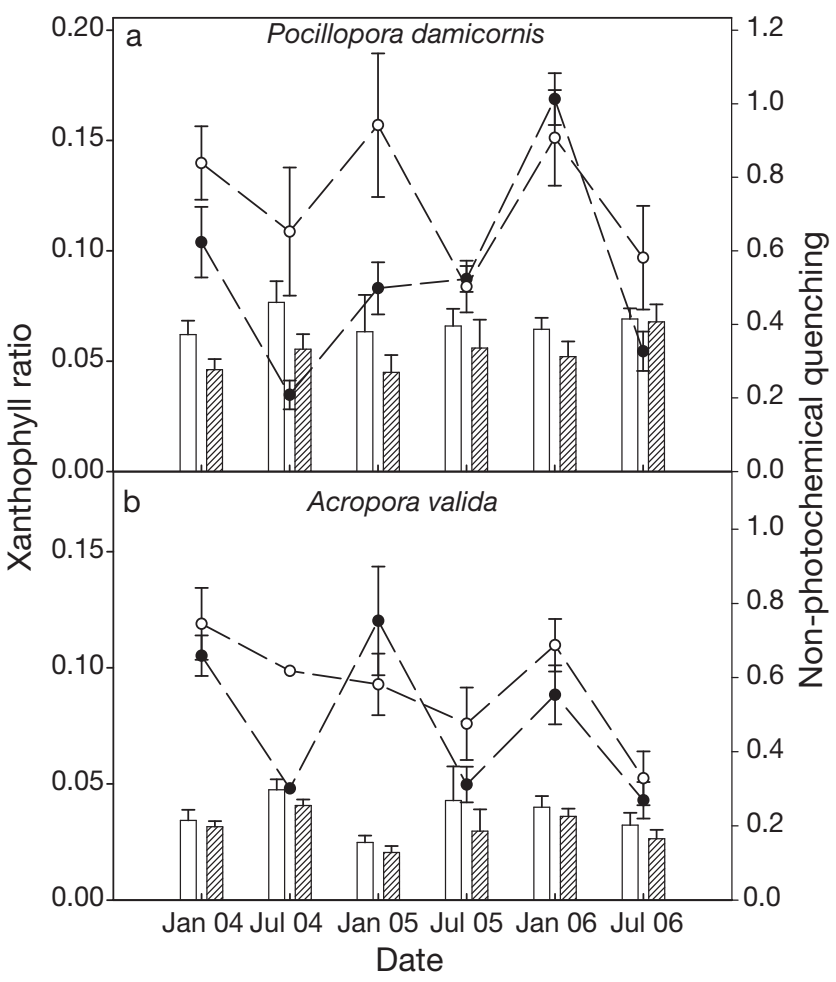

Fig. 5. (a) Pocillopora damicornis and (b) Acropora valida. Xanthophyll ratios (ratio of diatoxanthin to the sum of diatoxanthin + diadinoxanthin) on sun- (white bars) and shadeadapted surfaces (hatched bars) and non-photochemical quenching in sun- (O) and shade-adapted surfaces ( $(\bullet)$ of individual colonies. Xanthophyll ratio values are means $+\mathrm{SE}$; non-photochemical quenching values are means $\pm \mathrm{SE}, \mathrm{n}=10$ than shade-adapted surfaces $\left(F_{1,36}=7.40, \mathrm{p}=0.01\right)$, whereas $A$. valida had low levels of $D t$ to the total pool of Dn + Dt for both orientations of the branches (Fig. 5). Furthermore, $P$. damicornis colonies in summer had lower de-epoxidation than in winter $\left(F_{1,36}=5.84, \mathrm{p}=\right.$ $0.021)$. NPQ RLC $_{\text {was }}$ highest in summer $\left(F_{1,36}=29.71\right.$, $\mathrm{p}<0.001)$ and higher in sun-adapted than in shadeadapted surfaces of $P$. damicornis $\left(F_{1,36}=10.96, \mathrm{p}=\right.$ 0.002, Fig. 5a).

\section{DISCUSSION}

\section{Photochemical efficiency and photo-acclimatisation}

As expected, shade-adapted surfaces generally exhibited higher photochemical efficiency than sunadapted surfaces as indicated by the $\Phi_{\text {PSII }}$ (Pocillopora damicornis only) and $F_{\mathrm{v}} / F_{\mathrm{m}}$ values. In shade-adapted surfaces, $F_{\mathrm{v}} / F_{\mathrm{m}}$ decreased between dusk and dawn measurements (Fig. 3). This may be due to chlororespiration, which occurs in corals (Jones \& HoeghGuldberg 2001, Ulstrup et al. 2005) and is known to lower $F_{\mathrm{v}} / F_{\mathrm{m}}$ values unless far-red light treatment is applied.

There was an inverse relationship between $\Phi_{\text {PSII }}$ measured in sun- and shade-adapted surfaces among seasons in Pocillopora damicornis, whereby sunadapted surfaces yielded lower $\Phi_{\text {PSII }}$ in summer than in winter, and shade-adapted surfaces yielded higher $\Phi_{\text {PSII }}$ in summer than in winter (Fig. 2a). This suggests that sun-adapted surfaces are more sensitive to combined effects of higher temperature and irradiance in summer, as would be expected. In Acropora valida, the lack of significant variation between sun- and shadeadapted surfaces and the lack of a significant interaction between branch orientation and season may be partly due to seasonal changes in the relative abundance of different Symbiodinium types (Fitt et al. 2000, Thornhill et al. 2006). The symbiont consortia may be continually modified to allow acclimatisation to changes in the environment (Thornhill et al. 2006), promoting well-suited Symbiodinium types that may compensate physiologically for other types that do not perform as well. Furthermore, sun-adapted branches of A. valida at Heron Island are distinctly purple-pigmented, suggesting that host pigments may provide some photoprotection for symbionts (Salih et al. 2000, Dove 2004), thus avoiding significant decrease of $\Phi_{\mathrm{PSII}}$.

$F_{\mathrm{v}} / F_{\mathrm{m}}$ values were significantly lower in January 2004 and 2006 for both coral species, irrespective of branch orientation. A summer decline in $F_{\mathrm{v}} / F_{\mathrm{m}}$ is likely due to a combination of photo-damage and photoprotective processes (cf. Warner et al. 2002) as well as to coral bleaching, which occurred in January 2005. 
Interestingly, in January $2005, F_{\mathrm{v}} / F_{\mathrm{m}}$ remained similar to winter levels (Fig. 3) even though symbiont cell density declined significantly (Fig. 1) due to prolonged elevated seawater temperatures at Heron Island (available at: www.noaa.gov). This suggests that remnant Symbiodinium are not physiologically compromised, possibly through effective dissipation of excess excitation energy and, in the case of Acropora valida, also through changes in the genetic composition of the symbiotic communities (Fitt et al. 2000, Warner et al. 2002, Baker 2003).

$\Phi_{\text {PSII }}$ and $F_{\mathrm{v}} / F_{\mathrm{m}}$ measurements were collected with a Diving-PAM and a PEA instrument, respectively. Thus, direct comparison of these 2 parameters should be avoided when interpreting the data (due to differences in optics and intensity of the saturating flash). Furthermore, for corals, chlororespiration may lower $F_{\mathrm{v}} / F_{\mathrm{m}}$ relative to $\Phi_{\text {PSII }}$ (Jones \& Hoegh-Guldberg 2001, Hill \& Ralph 2005).

The FICs revealed physiological differences between sun- and shade-adapted surfaces of both coral species. The amplitudes of all 4 inflections along the transients were reduced in sun-adapted surfaces compared to shade-adapted surfaces (Fig. 4a-d), indicating inhibitory effects on PSII at each of these steps. The lower $\mathrm{O}$ step of sun-adapted surfaces can be attributed to a lower chlorophyll concentration within the tissue compared to the shade-adapted regions. As would be expected for the P step (indicating $F_{\mathrm{m}}$ ), the reduction was also reflected in lower $F_{\mathrm{v}} / F_{\mathrm{m}}$ values in sunadapted than shade-adapted surfaces. The decline in the $\mathrm{O}$ and $\mathrm{J}$ steps in July 2005 following the strong bleaching of Pocillopora damicornis in January 2005 suggests that damage occurred in PSII, which reduced electron flow to the primary electron acceptor $Q_{A}$ (Strasser et al. 1995, Ulstrup et al. 2005); elevated temperature during the previous summer may have been the causal agent. There was also a decline in the I and P steps at this time, which suggests some blockage of electron flow beyond $Q_{A}$ and reduced maximum capacity for electron flow, perhaps as a result of the prolonged exposure to elevated temperatures. In Acropora valida, the I and P steps recovered somewhat by July 2006, whereas the O and J steps remained low after January 2005, suggesting that PSII was intact and functioning, albeit photo-inhibited.

\section{Genetic diversity of Symbiodinium}

Many coral species are dominated by only one symbiont type (Goulet 2006, but see Baker \& Romanski 2007). Therefore, it is likely that the physiological flexibility of symbiont communities residing in corals must, in many instances, be large to cope with not only natural variation of the environment (Ulstrup et al. 2006b), but also rising seawater temperatures. This is the case for Pocillopora damicornis, which has high fidelity to symbiont type $\mathrm{C} 1$ (no other type was detected at any sampling time). This result supports previous findings by Ulstrup et al. (2006a) which show that $P$. damicornis has fidelity to $\mathrm{C} 1$ across the entire length of the Great Barrier Reef (GBR), with few exceptions. Coral colonies with such consistent symbioses are unlikely to respond to environmental shifts by changing to other Symbiodinium types (Thornhill et al. 2006).

In contrast, the genetically polymorphic zooxanthellar communities of Acropora valida varied over time and between sun- and shade-adapted surfaces. Although symbiont $\mathrm{C} 2$ was the predominant type, clade A appeared regularly, with a higher proportion of colonies hosting clade A in sun-adapted (10 to $67 \%$ ) than in shade-adapted surfaces (0 to $29 \%$ ) except for in the winter of 2005 (Table 2). The higher proportion of clade A in sun-adapted surfaces suggests that this Symbiodinium type may be adapted to high light. In the winter following the summer bleaching of 2005, more colonies contained clade A (71 to $100 \%$ ), possibly as a response to the past bleaching conditions (Table 2).

Several studies have found relatively high frequencies of clade A in a variety of invertebrate hosts in cooler climates (Loh et al. 2001, 2006, Savage et al. 2002a), whereas rare observations ( $<3 \%$ of samples) of clade A have been reported from other species of Acropora in tropical waters (van Oppen et al. 2001, 2005). Overall, the cooler climate at Heron Island than in other parts of the GBR (Ulstrup et al. 2006a) may favour the presence of clade A over other types that have been found in warmer parts of the GBR (Ulstrup \& van Oppen 2003).

\section{Symbiont cell density}

Corals sampled seasonally have variable symbiont cell density that is usually inversely correlated with increases in temperature and light (Stimson 1997, Fagoonee et al. 1999, Fitt et al. 2000). Both species we studied showed a significant decline in symbiont cell density in summer 2005 coincident with the bleaching hotspot at Heron Island. The reduction in symbiont density observed in summer 2005 in Acropora valida also coincided with an increase in the dominance of Symbiodinium clades A and C1 (Table 2). Although Symbiodinium C2 was still present in January 2005, a decline in dominance suggests that this type may be compromised during prolonged, elevated temperatures. 


\section{Photo-protection}

The de-epoxidation of Dn to form Dt is one of the nonphotochemical pathways by which excess excitation energy can be dissipated by PSII, and is elevated in corals undergoing bleaching (Lesser et al. 2000, Venn et al. 2006). This process is induced by light, and intensifies over the course of the morning (Brown et al. 1999a, Warner \& Berry-Lowe 2006). In the present study, we did not have the resources to follow the time course of the xanthophyll de-epoxidation and thus we measured the ratio of Dt to the sum of Dn + Dt concentration at dusk (25 to $35 \mu \mathrm{mol}$ photons $\mathrm{m}^{-2} \mathrm{~s}^{-1}$ ). Under these sub-saturating irradiance conditions, $<10 \%$ of Dn was de-epoxidised. Pocillopora damicornis showed greater degree of deepoxidation than Acropora valida (Fig. 5). This suggests that the 2 species of corals may use different mechanisms for acclimatisation. While $A$. valida colonies may change the relative abundance of different Symbiodinium types hosted, $P$. damicornis colonies may compensate for their inability to change their symbiont consortia by exhibiting greater capacity for xanthophyll cycling.

Corals may also differ in baseline de-epoxidation capacity depending on their irradiance history. Shadeexposed surfaces of Pocillopora damicornis had a lower degree of de-epoxidation than sun-exposed surfaces, probably as a result of greater requirement for excess energy dissipation in sun-exposed surfaces.

\section{SUMMARY}

The corals Pocillopora damicornis and Acropora valida were studied over $3 \mathrm{yr}$ to investigate photophysiological responses and genotypic character of Symbiodinium. P. damicornis harboured a single Symbiodinium type (C1). A. valida possessed Symbiodinium types $\mathrm{C} 1, \mathrm{C} 2$ and a member of clade $\mathrm{A}$, and the proportions of these changed seasonally. Marked changes in the photo-physiological characteristics were recorded in both corals. In P. damicornis, these were not attributable to changes in the Symbiodinium community but were brought about by changes in symbiont cell density, photochemical efficiency and xanthophyll cycle activity. In A. valida, these same changes probably operated in combination with genotypic changes in the Symbiodinium community.

Acknowledgements. We thank N. Ralph for fabrication of the dark-adaptation chamber, M. Chen for help and useful suggestions on HPLC analysis, A. Griffin and M. Goldner for valuable help in the laboratory and all staff at Heron Island Research Station. This research was supported jointly by the Australian Research Council, the Department of Environmental Science, UTS and a GBRMPA Science for management award and PADI grant to K.E.U.

\section{LITERATURE CITED}

Ambarsari I, Brown BE, Barlow RG, Britton G, Cummings D (1997) Fluctuations in algal chlorophyll and carotenoid pigments during solar bleaching in the coral Goniastrea aspera at Phuket, Thailand. Mar Ecol Prog Ser 159: 303-307

Baker AC (2003) Flexibility and specificity in coral-algal symbiosis: diversity, ecology, and biogeography of Symbiodinium. Annu Rev Ecol Evol Syst 34:661-689

> Baker AC, Romanski AM (2007) Multiple symbiotic partnerships are common in scleractinian corals, but not in octocorals: Comment on Goulet (2006). Mar Ecol Prog Ser 335: $237-242$

Beardall J, Quigg A (2003) Oxygen consumption: photorespiration and chlororespiration. In: Larkum AWD, Douglas SE, Raven JA (eds) Photosynthesis in algae. Kluwer, Dordrecht, p 157-181

Berkelmans R, van Oppen MJH (2006) The role of zooxanthellae in the thermal tolerance of corals: a 'nugget of hope' for coral reefs in an era of climate change. Proc $\mathrm{R}$ Soc Lond B Biol Sci 273:2305-2312

Bhagooli R, Hidaka M (2003) Comparison of stress susceptibility of in hospite and isolated zooxanthellae among five coral species. J Exp Mar Biol Ecol 291:181-197

Brown BE, Ambarsari I, Warner ME, Fitt WK, Dunne RP, Gibb SW, Cummings DG (1999a) Diurnal changes in photochemical efficiency and xanthophyll concentrations in shallow water reef corals: evidence for photoinhibition and photoprotection. Coral Reefs 18:99-105

Brown BE, Dunne RP, Ambarsari I, Le Tissier MDA, Satopoomin U (1999b) Seasonal fluctuations in environmental factors and variation in symbiotic algae and chlorophyll pigments in four Indo-Pacific coral species. Mar Ecol Prog Ser 191:53-69

> Brown BE, Downs CA, Dunne RP, Gibb SW (2002) Preliminary evidence for tissue retraction as a factor in photoprotection of corals incapable of xanthophyll cycling. J Exp Mar Biol Ecol 277:129-144

Chang SS, Prezelin BB, Trench RK (1983) Mechanisms of photoadaption in three strains of the symbiotic dinoflagellate Symbiodinium microadriaticum. Mar Biol 76:219-229

Dove S (2004) Scleractinian corals with photoprotective host pigments are hypersensitive to thermal bleaching. Mar Ecol Prog Ser 272:99-116

Enriquez S, Mendez ER, Iglesias-Prieto R (2005) Multiple scattering on coral skeletons enhances light absorption by symbiotic algae. Limnol Oceanogr 50:1025-1032

Fagoonee I, Wilson HB, Hassell MP, Turner JR (1999) The dynamics of zooxanthellae populations: a long-term study in the field. Science 283:843-845

Falkowski PG, Dubinsky Z (1981) Light-shade adaptation of Stylophora pistillata, a hermatypic coral from the Gulf of Eilat. Nature 289:172-174

Fitt WK, McFarland FK, Warner ME, Chilcoat GC (2000) Seasonal patterns of tissue biomass and densities of symbiotic dinoflagellates in reef corals and relation to coral bleaching. Limnol Oceanogr 45:677-685

> Garab G, Lajko F, Mustardy L, Marton L (1989) Respiratory control over photosynthetic electron transport electron in chloroplasts of higher-plant cells: evidence of chlororespiration. Planta 179:349-358

Gorbunov MY, Kolber ZS, Lesser MP, Falkowski PG (2001) Photosynthesis and photoprotection in symbiotic corals. Limnol Oceanogr 46:75-85

Goreau TJ, Hayes RL (1994) Coral bleaching and ocean 'hot spots'. Ambio 23:176-180 
Goulet TL (2006) Most corals may not change their symbionts. Mar Ecol Prog Ser 321:1-7

Goulet TL, Coffroth MA (2003) Stability of an octocoral-algal symbiosis over time and space. Mar Ecol Prog Ser 250: $117-124$

Goulet TL, Cook CB, Goulet D (2005) Effects of short-term exposure to elevated temperatures and light levels on photosynthesis of different host-symbiont combinations in the Aiptasia pallida/Symbiodinium symbiosis. Limnol Oceanogr 50:1490-1498

Govindjee (1995) Sixty-three years since Kautsky: chlorophyll a fluorescence. Aust J Plant Physiol 22:131-160

Hill R, Ralph PJ (2005) Diel and seasonal changes in fluorescence rise kinetics of three scleractinian corals. Funct Plant Biol 32:549-559

Hill R, Frankart C, Larkum AWD, Kühl M, Ralph PJ (2004a) Loss of functional photosystem II reaction centres in zooxanthellae of corals exposed to bleaching conditions: using fluorescence rise kinetics. Photosynth Res 82:59-72

Hill R, Schreiber U, Gademann R, Larkum AWD, Kühl M, Ralph PJ (2004b) Spatial heterogeneity of photosynthesis and the effect of temperature-induced bleaching conditions in three species of coral. Mar Biol 144:633-640

Iglesias-Prieto R, Trench RK (1994) Acclimation and adaptation to irradiance in symbiotic dinoflagellates. I. Responses of the photosynthetic unit to changes in photon flux density. Mar Ecol Prog Ser 113:163-175

Jeffrey SW, Mantoura RFC, Bjørnland T (1997) Data for the identification of 47 key phytoplankton pigments. In: Jeffrey SW, Mantoura RFC, Wright SW (eds) Phytoplankton pigments in oceanography: guidelines to modern methods. UNESCO Publishing, Paris, p 447-559

Jones RJ, Hoegh-Guldberg O (2001) Diurnal changes in the photochemical efficiency of the symbiotic dinoflagellates (Dinophyceae) of corals: photoprotection, photoinactivation and the relationship to coral bleaching. Plant Cell Environ 24:89-99

Jones RJ, Hoegh-Guldberg O, Larkum AWD, Schreiber U (1998) Temperature-induced bleaching of corals begins with impairment of the $\mathrm{CO}_{2}$ mechanism in zooxanthellae. Plant Cell Environ 21:1219-1230

Kühl M, Cohen Y, Dalsgaard T, Jørgensen BB, Revsbech NP (1995) Microenvironment and photosynthesis of zooxanthellae in scleractinian corals studied with microsensors for $\mathrm{O}_{2}, \mathrm{pH}$ and light. Mar Ecol Prog Ser 117: 159-172

Lavorel J, Etienne AL (1977) In vivo chlorophyll fluorescence. In: Barber J (ed) Primary processes of photosynthesis. Elsevier, Amsterdam, p 203-268

> Lazar D (2006) The polyphasic chlorophyll a fluorescence rise measured under high intensity of exciting light. Funct Plant Biol 33:9-30

> Lesser MP, Shick JM (1989) Photoadaptation and defenses against oxygen toxicity in zooxanthellae from natural populations of symbiotic cnidarians. J Exp Mar Biol Ecol 134:129-141

Lesser MP, Mazel C, Phinney D, Yentsch CS (2000) Light absorption and utilization by colonies of the congeneric hermatypic corals Montastraea faveolata and Montastraea cavernosa. Limnol Oceanogr 45:76-86

Levy O, Dubinsky Z, Schneider K, Achituv Y, Zakai D, Gorbunov MY (2004) Diurnal hysteresis in coral photosynthesis. Mar Ecol Prog Ser 268:105-117

> Levy O, Dubinsky Z, Achituv Y, Erez J (2006) Diurnal polyp expansion behavior in stony corals may enhance carbon availability for symbionts photosynthesis. J Exp Mar Biol Ecol 333:1-11
Little AF, van Oppen MJH, Willis BL (2004) Flexibility in algal endosymbioses shapes growth in reef corals. Science 304: 1492-1494

Loh WKW, Loi T, Carter D, Hoegh-Guldberg O (2001) Genetic variability of the symbiotic dinoflagellates from the wide ranging coral species Seriatopora hystrix and Acropora longicyathus in the Indo-West Pacific. Mar Ecol Prog Ser 222:97-107

Loh WKW, Cowlishaw M, Wilson NG (2006) Diversity of Symbiodionium dinoflagellate symbionts from the Indo-Pacific sea slug Pteraeolidia ianthina (Gastropoda: Mollusca). Mar Ecol Prog Ser 320:177-184

Peltier G, Cournac L (2002) Chlororespiration. Annu Rev Plant Biol 53:523-550

Platt T, Gallegos CL, Harrison WG (1980) Photoinhibition of photosynthesis in natural assemblages of marine phytoplankton. J Mar Res 38:687-701

Porter JW, Muscatine L, Dubinsky Z, Falkowski PG (1984) Primary production and photoadaptation in light and shade-adapted colonies of the symbiotic coral, Stylophora pistillata. Proc R Soc Lond B 222:161-180

Quinn GP, Keough MJ (2002) Experimental design and data analysis for biologists. Cambridge University Press, Cambridge

Ralph PJ, Gademann R, Larkum AWD, Kühl M (2002) Spatial heterogeneity in active chlorophyll fluorescence and PSII activity of coral tissues. Mar Biol 141:639-646

Ralph PJ, Schreiber U, Gademann R, Kühl M, Larkum AWD (2005) Coral photobiology studied with a new imaging pulse amplitude modulated fluorometer. J Phycol 41: 335-342

> Robison JD, Warner ME (2006) Differential impacts of photoacclimation and thermal stress on the photobiology of four different phylotypes of Symbiodinium (Pyrrhophyta). J Phycol 42:568-579

> Rowan R (2004) Thermal adaptation in reef coral symbionts. Nature 430:742

Salih A, Larkum AWD, Cox G, Kühl M, Hoegh-Guldberg O (2000) Fluorescent pigments in corals are photoprotective. Nature 408:850-853

Savage AM, Goodson MS, Visram S, Trapido-Rosenthal H, Wiedenmann J, Douglas AE (2002a) Molecular diversity of symbiotic algae at the latitudinal margins of their distributions: dinoflagellates of the genus Symbiodinium in corals and sea anemones. Mar Ecol Prog Ser 244:17-26

Savage AM, Trapido-Rosenthal H, Douglas AE (2002b) On the functional significance of molecular variation in Symbiodinium, the symbiotic algae of Cnidaria: photosynthetic response to irradiance. Mar Ecol Prog Ser 244:27-37

Srivastava A, Guissé B, Greppin H, Strasser RJ (1997) Regulation of antenna structure and electron transport in PSII of Pisum sativum under elevated temperature probed by the fast polyphasic chlorophyll a fluorescence transient: OKJIP. Biochim Biophys Acta 1320:95-106

Stimson J (1997) The annual cycle of density of zooxanthellae in the tissues of field and laboratory-held Pocillopora damicornis (Linnaeus). J Exp Mar Biol Ecol 214:35-48

Stimson J, Kinzie RA III (1991) The temporal pattern and rate of release of zooxanthellae from the reef coral Pocillopora damicornis (Linnaeus) under nitrogen enrichment and control conditions. J Exp Mar Biol Ecol 153:63-74

Strasser RJ, Srivastava A, Govindjee (1995) Polyphasic chlorophyll a fluorescence transient in plants and cyanobacteria. Photochem Photobiol 61:32-42

Tchernov D, Gorbunov MV, de Vargas C, Yadav SN, Milligan AJ, Häggblom M, Falkowski PG (2004) Membrane lipids of symbiotic algae are diagnostic of sensitivity to 
thermal bleaching in corals. Proc Natl Acad Sci USA 101: 13531-13535

Thornhill DJ, LaJeunesse TC, Kemp DW, Fitt WK (2006) Multi-year, seasonal genotypic surveys of coral-algal symbioses reveal prevalent stability or post-bleaching reversion. Mar Biol 148:711-722

Toller WW, Rowan R, Knowlton N (2001) Zooxanthellae of the Montastraea annularis species complex: patterns of distribution of four taxa of Symbiodinium on different reefs and across depths. Biol Bull 201:348-359

Ulstrup KE, van Oppen MJH (2003) Geographic and habitat partitioning of genetically distinct zooxanthellae (Symbiodinium) in Acropora corals on the Great Barrier Reef. Mol Ecol 12:3477-3484

Ulstrup KE, Hill R, Ralph PJ (2005) Photosynthetic impact of hypoxia on in hospite zooxanthellae in the scleractinian coral Pocillopora damicornis. Mar Ecol Prog Ser 286: 125-132

Ulstrup KE, Berkelmans R, Ralph PJ, van Oppen MJH (2006a) Variation in bleaching sensitivity of two coral species across a latitudinal gradient on the Great Barrier Reef: the role of zooxanthellae. Mar Ecol Prog Ser 314:135-148

- Ulstrup KE, Ralph PJ, Larkum AWD, Kühl M (2006b) Intracolonial variability in light acclimation of zooxanthellae in coral tissues of Pocillopora damicornis. Mar Biol 149: 1325-1335

Editorial responsibility: Otto Kinne, Oldendorf/Luhe, Germany van Oppen MJH, Palstra FP, Piqueet AMT, Miller DJ (2001) Patterns of coral-dinoflagellate associations in Acropora: significance of local availability and physiology of Symbiodinium strains and host-symbiont selectivity. Proc R Soc Lond B Biol Sci 268:1759-1767

van Oppen MJH, Mahiny AJ, Done TJ (2005) Geographic distribution of zooxanthella types in three coral species on the Great Barrier Reef sampled after the 2002 bleaching event. Coral Reefs 24:482-487

Venn AA, Wilson MA, Trapido-Rosenthal HG, Keely BJ, Douglas A (2006) The impact of coral bleaching on the pigment profile of the symbiotic alga, Symbiodinium. Plant Cell Environ 29:2133-2142

- Warner ME, Berry-Lowe (2006) Differential xanthophyll cycling and photochemical activity in symbiotic dinoflagellates in multiple locations of three species of Caribbean coral. J Exp Mar Biol Ecol 339:86-95

> Warner ME, Fitt WK, Schmidt GW (1996) The effect of elevated temperature on the photosynthetic efficiency of zooxanthellae in hospite from four different species of reef coral: a novel approach. Plant Cell Environ 19: 291-299

Warner ME, Chilcoat GC, McFarland FK, Fitt WK (2002) Seasonal fluctuation in the photosynthetic capacity of photosystem II in symbiotic dinoflagellates in the Caribbean reef-building coral Montastraea. Mar Biol 141:31-38

Submitted: September 12, 2007; Accepted: November 27, 2007 Proofs received from author(s): May 6, 2008 